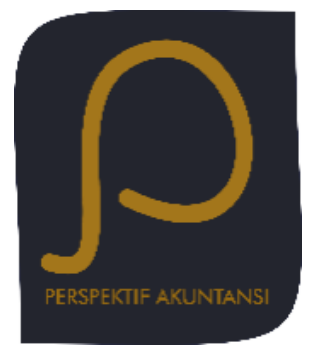

Perspektif Akuntansi

Volume 2 Nomor 2 (Juni 2019), hal. 169-193

ISSN: 2623-0194(Print), 2623-0186(Online) Copyright@ The Authors(s). All Rights Reserved

Fakultas Ekonomika dan Bisnis,

Universitas Kristen Satya Wacana

DOI: https://doi.org/10.24246/persi.v1i2.p169-193

http://ejournal.uksw.edu/persi

\title{
Analisis Implementasi Pengelolaan Dana Desa Menggunakan Aplikasi Siskeudes Desa Banyuanyar
}

\author{
Angela Ayu Wilma Atintyasputri ${ }^{1}$ \\ Fakultas Ekonomika dan Bisnis, Universitas Kristen Satya Wacana \\ Aprina Nugrahesthy Sulistya Hapsari \\ Fakultas Ekonomika dan Bisnis, Universitas Kristen Satya Wacana
}

Received Abstract. This research purpose to analyze the stages of village financial 02 April 2019 management according to Permendagri 113 of 2014 with the stages of village fund management in the Banyuanyar Boyolali Village by using the

Accepted application of Siskeudes. This research is a qualitative descriptive study.

25 Juni 2019 Data acquired by interviews and documentation. Qualitative analysis method used are data reduction, triangulation, data presentation and conclusion.The results and discussion of this research indicate that the stages of village financial management Permendagri 113 of 2014 with the stages of village funds management starting from the stages of planning, implementation, administration, reporting and accountability through the application of Siskeudes (Version V1.2.RI.0.6) in Banyuanyar is well implemented. Although there are differences in the implementation of accountability, that do not inputting process accountability reports by the application of Siskeudes, but only to complete the attachments needed as evidence in reporting accountability, but does not affect the process of village fund management Banyuanyar Application of Siskeudes can be monitoring of village financial management, seen from all input of village fund management in Banyuanyar by the application of Siskeudes online by information on place, time and date in real time and directly connected with Boyolali Regency server.

Keywords: Siskeudes, village fund, supervision 


\begin{abstract}
Abstrak. Penelitian ini bertujuan untuk menganalisis antara tahapan pengelolaan keuangan desa menurut Permendagri 113 Tahun 2014 dengan tahapan pengelolaan dana desa di Desa Banyuanyar Boyolali dengan menggunakan aplikasi Siskeudes. Penelitian ini merupakan penelitian deskriptif kualitatif. Data diperoleh melalui wawancara dengan bukti dokumentasi. Teknik analisis kualitatif yang digunakan yaitu reduksi data, triangulasi, penyajian data dan penarikan kesimpulan. Hasil dan pembahasan penelitian ini menunjukkan bahwa tahapan pengelolaan keuangan desa Permendagri 113 Tahun 2014 dengan tahapan pengelolaan dana desa mulai dari tahapan perencanaan, pelaksanaan, penatausahaan, pelaporan dan pertanggungjawaban melalui aplikasi Siskeudes (Versi V1.2.RI.0.6) di Desa Banyuanyar Boyolali sudah terimplementasikan dengan baik. Namun terdapat sedikit perbedaan pada pengimplementasian tahapan pertanggungjawaban yang tidak melakukan proses penginputan pada laporan pertanggungjawaban melalui aplikasi Siskeudes, namun peran Siskeudes hanya melengkapi lampiran-lampiran yang dibutuhkan sebagai bukti dalam pelaporan pertanggungjawaban, tetapi hal tersebut tidak mempengaruhi proses pengelolaan dana desa Banyuanyar. Aplikasi Siskeudes dapat dijadikan sebagai sarana pengawasan pengelolaan keuangan desa, dilihat dari seluruh penginputan pengelolaan dana desa di Desa Banyuanyar melalui aplikasi Siskeudes secara online dengan menyertakan keterangan tempat, waktu dan tanggal secara real time dan langsung terhubung dengan server Kabupaten Boyolali.
\end{abstract}

Kata kunci: Siskeudes, dana desa, pengawasan

\title{
Pendahuluan
}

Dalam rangka memperbaiki dan meningkatkan kesejahteraan rakyat, pemerintah pusat memberikan kesempatan kepada masing-masing pemerintah daerah agar setiap desa dapat berkembang dengan mandiri. Pemberian kepercayaan kepada daerah bertujuan untuk meningkatkan daya saing daerah, pendapatan daerah dan selalu mengutamakan kepentingan dan kesejahteraan masyarakat desa setempat. Peluang tersebut dimanfaatkan oleh Kepala Desa Banyuanyar Boyolali untuk mewujudkan Desa Banyuanyar sebagai Green Smart Village. Salah satu bentuk cara untuk mendukung tercapainya tujuan tersebut, adalah dengan program yang dilakukan oleh Kepala Desa Banyuanyar Boyolali yakni mendirikan Desa Berbasis Teknologi Informasi (TI) dengan sepuluh titik wifi hotspot yang telah terpasang di seluruh desa dan diharapkan dapat memudahkan akses masyarakat dan mempercepat informasi sekaligus mampu memanfaatkan potensi-potensi yang ada di Desa Banyuanyar melalui jalur online (Banyuanyar 2017). Selain itu Pemerintah Desa Banyuanyar juga telah membuat Website Desa yang dilengkapi dengan Information and Communication Technology Center (ICT Center) untuk mengedukasi masyarakat desa. 
Dalam rangka mewujudkan Green Smart Village, maka Desa Banyuanyar Boyolali menggunakan dana desa yang bersumber dari Anggaran Pendapatan dan Belanja Negara (APBN) di tahun 2017, yaitu sebesar Rp 786.272.000,00 (Banyuanyar 2017). Dana desa harus dapat dikelola dengan baik demi terciptanya tata kelola keuangan desa yang bersih, tertib, transparan dan akuntabel, terkait hal tersebut peran pengawasan sangat penting untuk keberlangsungan proses pengelolaan dana desa. Data Indonesian Corruption Watch (ICW) sampai dengan tahun 2018 telah menemukan sebanyak 100 kasus korupsi di tingkat desa pada sektor penganggaran desa (Putra 2018). Oleh sebab itu ICW menghimbau untuk memprioritaskan pengawasan dalam pengelolaan dana desa.

Salah satu bentuk komitmen dari pemerintah dalam mendukung pengawasan pengelolaan dana desa tercantum dalam Surat Edaran Direktur Jenderal Bina Pemerintahan Desa Kementerian Dalam Negeri nomor 145/8350/BPD tanggal 27 November 2015 tentang Aplikasi Pengelolaan Keuangan Desa yang menyatakan bahwa Badan Pemeriksa Keuangan dan Pembangunan (BPKP) telah bekerja sama dengan Kementrian Desa Pembangunan Daerah Tertinggal dan Transmigrasi (PDTT) mengembangkan sistem pengelolaan dana desa berbasis aplikasi yaitu aplikasi Sistem Keuangan Desa (Siskeudes). Aplikasi Siskeudes sebelumnya sudah dikenal dengan nama aplikasi Sistem Informasi Manajemen Daerah (SIMDA), yang dibuat sebelum terbentuknya kebijakan dana desa, dengan tujuan untuk menciptakan laporan keuangan yang akuntabel. Seiring dengan sahnya Undang-Undang Nomor 6 Tahun 2014 tentang Desa di Indonesia, BPKP merancang aplikasi Siskeudes secara integrasi dan sederhana yang dapat membantu mengawasi pengelolaan dana desa (Peraturan Pemerintah Indonesia 2014). Pengawasan terhadap pengelolaan dana desa mencakup dari tahap perencanaan, pelaksanaan, penatausahaan, pelaporan sampai pertanggungjawaban keuangan desa.

Selain sebagai sarana pengawasan, tujuan lain dari diterapkannya aplikasi Siskeudes adalah untuk memudahkan dalam pelaporan keuangan, sehingga diharapkan dapat meningkatkan pengelolaan dan laporan pertanggungjawaban keuangan desa. BPKP telah merancang fitur-fitur dalam aplikasi Siskeudes secara integrasi, sederhana dan user friendly sehingga pengguna mudah dalam mengoperasikannya (BPKP 2015). Selain itu aplikasi Siskeudes juga telah dilengkapi dengan Sistem Pengendalian Intern (Built-in Internal Control). BPKP juga melakukan kerjasama dengan Kementerian Dalam Negeri untuk meningkatkan akuntabilitas pengelolaan keuangan desa dengan melakukan pengembangan tata kelola keuangan desa melalui aplikasi Siskeudes. Tingkat implementasi aplikasi Siskeudes telah mencapai 33,17 persen atau 24.863 dari 74.954 desa di seluruh Indonesia, salah satunya 
termasuk Desa Banyuanyar Boyolali (Kementerian Komunikasi dan Informatika Republik Indonesia 2017). Penerapan aplikasi Siskeudes sangat mendukung program Pemerintah daerah Kabupaten Boyolali yang terpilih menjadi salah satu di antara 50 daerah dalam program kerja Kementerian Komunikasi dan Informatika (Kemenkominfo) yaitu menciptakan 100 Smart City (Boyolali 2018).

Penelitian tentang aplikasi Siskeudes mulai bermunculan seiring dengan diterapkannya aplikasi Siskeudes pada tahun 2015 di Indonesia. Salah satunya penelitian yang dilakukan Afrizal et al. (2016) yang menyatakan bahwa dalam pengelolaan keuangan Desa Sungai Pinang dengan menggunakan aplikasi Siskeudes terdapat permasalahan berupa belum tersedianya SDM yang memadai dalam menggunakan aplikasi Siskeudes. Penelitian lain yang dilakukan Pulungan (2013) menunjukkan tentang hasil kajian implementasi aplikasi Sistem Informasi Manajemen Daerah (SIMDA) di Kutai Kartanegara relatif telah cukup tinggi. SIMDA dapat dilakukan diatas rata-rata standar yang ditetapkan regulasi. Sumber daya manusia terhadap kesiapan dalam implementasi SIMDA relatif cukup baik serta dukungan jaringan sudah cukup tinggi. Software SIMDA diakui cukup bagus, namun cukup rentan dengan serangan virus.

Penelitian lain menyatakan bahwa sistem informasi mempermudah pihak kantor Desa Pringkuku dalam proses pengelolaan keuangan, membantu dalam proses penginputan data, pencarian data, dan laporan data uang, dapat meminimalisasi adanya kesalahan dan mengoptimalkan keamanan data (Rusmayanti et al. 2010). Pada hasil penelitian Juardi et al. (2018) mengungkapkan bahwa pengelolaan aplikasi Siskeudes di Desa Jennetallsa, Kecamatan Pallangga, Kabupaten Gowa sudah terstruktur dengan baik dan dalam proses pelaporannya telah melakukan proses pertanggungjawabannya dengan relevan. Penelitian Darwin (2017) menunjukkan bahwa implementasi Siskeudes memberikan dampak yang cukup baik dari segi efisiensi waktu dan biaya. Informasi Siskeudes dalam pengelolaan Alokasi Dana Desa dapat menciptakan akuntabilitas pengelolaan Alokasi Dana Desa.

Pembangunan desa berbasis teknologi informasi merupakan salah satu bukti pemanfaatan dana desa yang dilakukan oleh Desa Banyuanyar untuk mewujudkan Green Smart Village. Desa Banyuanyar juga telah dilengkapi dengan fasilitas seperti perpustakaan desa, Pos Kesehatan Desa, dan BUMDes. Selain lengkapnya fasilitas, Desa Banyuanyar juga telah membentuk beberapa lembaga kemasyarakatan, antara lain Badan Permusyawaratan Desa (BPD), Lembaga Pemberdayaan Masyarakat Desa (LPMD), Gabungan Kelompok Tani, dan Karangtaruna. Selain faktor-faktor tersebut yang menjadi alasan penelitian ini memilih Desa Banyuanyar sebagai objek penelitian adalah Desa Banyuanyar 
telah menerapkan aplikasi Siskeudes untuk mengelola dana desa. Sementara itu pokok yang menjadi permasalahan dalam penelitian ini adalah Desa Banyuanyar sudah memiliki struktur teknologi informasi yang memadai, sehingga tentunya untuk dapat mengimplementasikan Siskeudes bukan masalah yang sulit.

Penelitian Dewanti et al. (2016) menunjukkan bahwa pada tahap perencanaan pengelolaan keuangan di Desa Boreng dengan perencanaan pengelolaan keuangan desa menurut Permendagri No. 37 tahun 2007 banyak sekali ketidaksesuaiannya. Penelitian ini bermaksud untuk menganalisis implementasi antara tahapan pengelolaan keuangan desa berdasarkan Permendagri 113 Tahun 2014 dengan tahapan pengelolaan dana desa di Desa Banyuanyar Boyolali dengan menggunakan aplikasi Siskeudes. Penelitian ini juga menganalisis implementasi setiap tahapan pengelolaan dana desa yang sebenarnya pada desa Banyuanyar dengan menggunakan aplikasi Siskeudes. Pada penelitian sebelumnya belum ada yang menganalisis implementasi setiap tahapan pengelolaan dana desa dengan menggunakan aplikasi Siskeudes, penelitian sebelumnya hanya menganalisis pada pengelolaan dana desa saja. Implementasi perlu dianalisis karna berhubungan dengan salah satu fungsi dari aplikasi Siskeudes yaitu sebagai sarana pengawasan pengelolaan dana desa (Peraturan Pemerintah Indonesia 2014).

Hasil penelitian ini diharapkan dapat bermanfaat, terutama bagi Desa Banyuanyar Boyolali, diharapkan penelitian ini dapat dijadikan sebagai bahan evaluasi dalam penggunaan aplikasi Siskeudes. Bagi Pemerintah, diharapkan penelitian ini dapat memberikan masukan dalam pengembangan aplikasi Siskeudes terhadap pemberian kebijakan, sehingga dalam penggunaannya tidak adanya perbedaan pandangan antara pemerintah pusat, daerah, desa, dan juga masyarakat. Bagi Akademis diharapkan dapat memberikan wawasan mengenai implementasi dari aplikasi Siskeudes. Selain itu, penelitian ini dapat dijadikan sebagai acuan atau referensi bagi penelitian selanjutnya.

\section{Telaah Pustaka}

\section{Desa dan Dana Desa}

Bermula munculnya wujud Nawa Cita ke-3 Presiden Jokowi, yaitu membangun Indonesia dari pinggiran dengan memperkuat daerah-daerah dan desa dalam kerangka NKRI, keberadaan desa kini telah diakui oleh Undang-Undang Nomor 6 Tahun 2014 tentang Desa dan telah berada di tingkat paling rendah dalam pemerintahan. Pengertian desa yang tercantum dalam Undang-Undang Nomor 6 Tahun 2014 pasal 1, desa adalah kesatuan masyarakat hukum yang memiliki batas wilayah yang berwenang untuk mengatur dan mengurus urusan 
pemerintahan, kepentingan masyarakat setempat berdasarkan prakarsa masyarakat, hak asal usul, dan/atau hak tradisional yang diakui dan dihormati dalam sistem pemerintahan Negara Kesatuan Republik Indonesia (Peraturan Pemerintah Indonesia 2014). Pentingnya melakukan pembangunan kawasan di perdesaan yaitu untuk mewujudkan kemandirian masyarakat sehingga dapat menciptakan desa-desa mandiri yang memiliki ketahanan sosial, ekonomi, dan penguatan keterkaitan kegiatan ekonomi kota-desa (Kementrian Keuangan Republik Indonesia 2017).

Dana desa merupakan dana yang bersumber dari Anggaran Pendapatan dan Belanja Negara (APBN) bagi desa yang ditransfer melalui Anggaran Pendapatan dan Belanja Daerah Kabupaten/Kota dan digunakan untuk membiayai pemerintahan, pembangunan, serta pemberdayaan masyarakat. Rustiarini (2016) menyatakan bahwa dana desa memiliki potensi yang tinggi untuk meningkatkan kualitas hidup masyarakat desa. Dana desa yang dibagikan untuk masing-masing desa berbeda, pertimbangan pembagian dana desa dalam rangka memajukan kesejahteraan dan pemerataan pembangunan desa dinilai berdasarkan dari jumlah penduduk, angka kemiskinan, luas wilayah, dan tingkat kesulitan geografis. Berdasarkan Undang-Undang Nomor 6 Tahun 2014, dana desa memiliki tujuan, antara lain untuk meningkatkan pelayanan publik di desa, mengentaskan kemiskinan, memajukan perekonomian desa, mengatasi kesenjangan pembangunan antar desa, dan memperkuat masyarakat desa sebagai subjek dari pembangunan (Peraturan Pemerintah Indonesia 2014).

\section{Pengelolaan Keuangan Desa}

Tahapan pengelolaan keuangan desa merupakan serangkaian kegiatan yang mencakup tahap perencanaan, pelaksanaan, penatausahaan, pelaporan dan pertanggungjawaban yang diatur dalam Peraturan Menteri Dalam Negeri Nomor 113 Tahun 2014 (Peraturan Pemerintah Indonesia 2014). Tahapan ini diawali dengan perencanaan, yang merupakan proses untuk menentukan dengan tepat tindakan di masa yang akan datang, melalui tahapan pilihan dan dengan memperkirakan sumber daya yang tersedia (Murtiono dan Wulandari 2014). Kegiatan perencanaan meliputi menyusun Rancangan Peraturan Desa mengenai APBDes atas dasar RKPDes tahun yang bersangkutan oleh sekretaris desa dan disampaikan kepada kepala desa. Kepala desa bersama dengan BPD membahas dan menyepakati Rancangan Peraturan Desa.

Tahapan pengelolaan keuangan desa selanjutnya adalah pelaksanaan. Pelaksanaan merupakan seluruh proses pengeluaran dan penerimaan dilakukan menggunakan rekening kas desa dengan dukungan bukti yang lengkap dan sah. Bendahara dapat menyimpan uang dalam rekening desa dan besarannya ditetapkan oleh bupati/walikota. Tim pelaksana kegiatan 
mengajukan Surat Permintaan Pembayaran (SPP) dengan melampirkan pernyataan tanggungjawab belanja serta bukti transaksi yang telah diperiksa kebenaran dan kelengkapannya oleh sekretaris desa kemudian meminta persetujuan pembayaran kepada kepala desa.

Tahapan ketiga dari pengelolaan keuangan desa yaitu penatausahaan, Lapananda (2016) menyatakan bahwa penatausahaan pengelolaan keuangan desa merupakan kegiatan mengatur keuangan desa untuk mewujudkan asas pengelolaan keuangan desa yang meliputi asas transparan dan asas akuntabel. Kegiatan dari tahapan penatausahaan meliputi semua kegiatan penerimaan dan pengeluaran kas dan melakukan tutup buku setiap akhir bulan secara tertib. Pihak yang bertanggungjawab dalam tahapan penatausahaan adalah bendahara desa.

Tahapan selanjutnya terkait dengan pengelolaan keuangan desa adalah tahap pelaporan yang merupakan suatu kewajiban yang harus dilakukan oleh aparat desa kepada Pemerintah Daerah dan pelaporan haruslah dilaksanakan secara tepat waktu dan bersifat akurat (Mamuaya et al. 2017). Kepala desa menyampaikan laporan realisasi pelaksanaan APBDes semester pertama dan semester akhir kepada bupati/walikota. Laporan realisasi pelaksanaan APBDes semester pertama disampaikan paling lambat akhir bulan Juli dan laporan semester akhir tahun paling lambat pada bulan Januari.

Setelah melalui tahapan pelaporan, tahapan terakhir dari pengelolaan keuangan desa yaitu pertanggungjawaban. Mariana dan Handayani (2014) menyatakan pertanggungjawaban merupakan proses penyampaian laporan kegiatan keuangan desa, baik itu penerimaan, pengeluaran, pembiayaan selama satu tahun anggaran. Laporan pertanggungjawaban realisasi pelaksanaan APBDes disampaikan oleh kepala desa kepada bupati/walikota setiap akhir tahun anggaran.

Laporan pertanggungjawaban realisasi pelaksanaan yang disampaikan meliputi, pendapatan, belanja dan pembiayaan dengan format laporan realisasi APBDes sesuai dengan peraturan desa yang dibentuk oleh bupati/walikota. Laporan pertanggungjawaban harus diinformasikan kepada masyarakat baik secara tertulis maupun melalui media informasi yang mudah diakses oleh masyarakat. Menurut penjelasan mengenai tahapan pengelolaan keuangan desa dapat dilihat pada Gambar 1. 


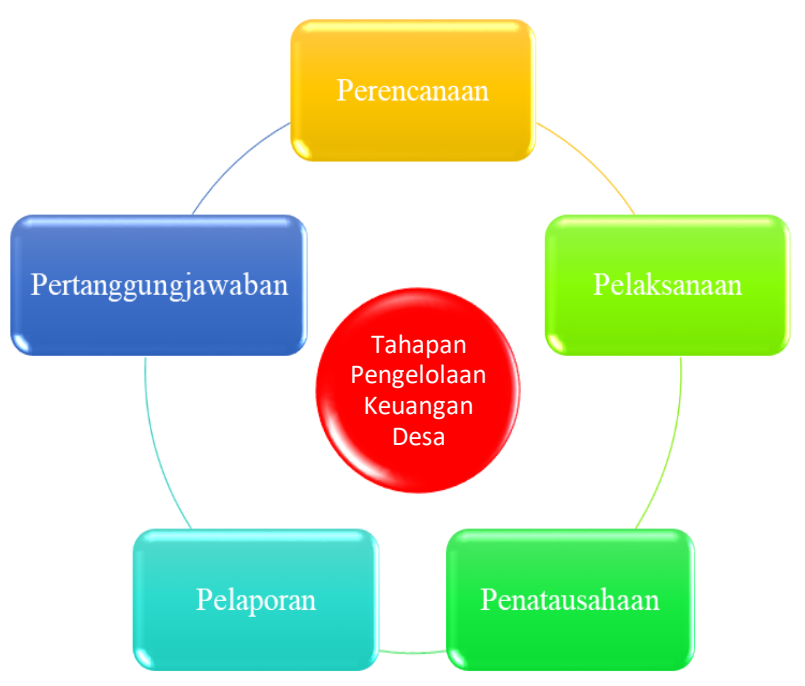

\section{Gambar 1. Tahapan Pengelolaan Keuangan Desa}

\section{Aplikasi Sistem Keuangan Desa (Siskeudes)}

Salah satu bentuk komitmen dari BPKP untuk mengawal akuntabilitas keuangan dan pembangunan nasional, serta sebagai salah satu bentuk pengawasan dalam pengelolaan keuangan desa dalam rangka penerapan, BPKP mengembangkan sistem dengan menggunakan database Microsoft Access untuk pengelolaan keuangan desa yaitu, aplikasi Siskeudes. Semula aplikasi ini dikembangkan oleh Perwakilan BPKP Sulawesi Barat yang dijadikan sebagai contoh proyek di lingkungan BPKP bulan Mei 2015. Pada bulan Juni 2015 aplikasi Siskeudes diimplementasikan secara perdana di Pemerintah Kabupaten Masama. Keberhasilan pengembangan aplikasi Siskeudes, kemudian diserahkan kepada Deputi Kepala BPKP Bidang Pengawasan Penyelenggaraan Keuangan Daerah di Jakarta. Pada tanggal 13 Juli 2015 aplikasi Siskeudes resmi diluncurkan (BPKP 2015).

Penggunaan aplikasi Siskeudes harus mendapat persetujuan dengan cara memberikan kode validasi Pemerintah Daerah yang dikeluarkan secara resmi oleh BPKP selaku pengembang aplikasi. Tujuan ditetapkannya aplikasi Siskeudes, yaitu yang pertama memastikan seluruh ketentuan dan kebijakan dalam implementasi Undang-Undang Nomor 6 Tahun 2014 terutama terkait keuangan dan pembangunan desa dapat dilaksanakan dengan baik pada tingkatan Pemerintah (Peraturan Pemerintah Indonesia 2014). Tujuan yang kedua Pemerintah Desa dapat melaksanakan siklus pengelolaan keuangan desa secara akuntabel mulai dari perencanaan, pelaksanaan, penatausahaan, pelaporan dan pertanggungjawaban. 
BPKP bersama dengan Aparat Pengawasan Intern Pemerintah (APIP) yang terdiri dari Inspektorat Kementerian/Lembaga dan Pemerintah Daerah melalui aplikasi Siskeudes akan meningkatkan pengawalan desa untuk memperkuat sistem pengendalian internal pengelolaan keuangan desa. Pentingnya transparansi atas pengelolaan keuangan desa membuat BPKP perlu berkoordinasi dengan KPK untuk menghimbau pengimplementasian Siskeudes yang ditunjukkan dalam Surat Edaran Komisi Pemberantasan Korupsi nomor B.7508/01-16/08/2016. Selama melakukan penyebarluasan aplikasi Siskeudes, BPKP juga bekerja sama dengan beberapa perguruan tinggi dan Ikatan Akuntan Indonesia (Kementerian Komunikasi dan Informatika Republik Indonesia 2017).

Basori et al. (2016) menyatakan bahwa aplikasi Siskeudes dapat dioperasikan dengan baik pada operating system Windows seperti WindowsXP, Windows7 dan Windows8. Selain dengan menggunakan operating system Windows tersebut, maka aplikasi Siskeudes tidak dapat diimplementasikan. Output yang dihasilkan dari aplikasi Siskeudes berupa dokumen penatausahaan dan laporan-laporan yang sesuai dengan ketentuan perundang-undangan, antara lain sebagai berikut: 1) Dokumen Penatausahaan terdiri dari bukti penerimaan, Surat Permintaan Pembayaran (SPP), dan Surat Setoran Pajak (SSP); 2) Laporan-laporan yang terdiri dari laporan penganggaran (APBDes, RAB, APBDes per sumber dana), dan laporan penatausahaan (Buku Kas Umum, Buku Bank, Buku Pajak, Buku Pembantu, dan Register dokumen penatausahaan).

Modul atau menu yang tersedia dalam melakukan tahapan pengelolaan dana desa melalui aplikasi Siskeudes yaitu dalam menu data entri terdapat empat modul yaitu, perencanaan, penganggaran, penatausahaan dan pembukuan. Fungsi modul perencanaan untuk menginput Visi, Misi, Tujuan dan Sasaran Pemerintah Desa yang telah dituangkan dalam RPJMDes. Modul kedua merupakan modul penganggaran untuk menginput data mengenai penyusunan APBDes pada awal tahun anggaran, usulan anggaran dan perubahan anggaran. Modul selanjutnya yaitu modul penatausahaan, untuk melakukan proses input dalam rangka pelaksanaan APBDes dan digunakan untuk mencatat transaksi penerimaan desa, transaksi pengeluaran desa, transaksi mutasi kas dan transaksi penyetoran pajak. Modul terakhir dalam menu data entri yaitu modul pembukuan, untuk menginput saldo awal dan melakukan penyesuaian jurnal. Output yang dihasilkan dari modul pembukuan yaitu, Laporan Realiasi Anggaran Bulanan/Triwulan/Semester/Akhir Tahun Anggaran, Laporan Kekayaan Milik Desa, Laporan Realiasi Penggunaan Dana Desa dan Laporan Kompilasi. 


\section{Metoda Penelitian}

\section{Jenis Penelitian dan Teknik Pengumpulan Data}

Penelitian ini dilakukan di Desa Banyuanyar, Kecamatan Ampel, Kabupaten Boyolali. Jenis penelitian ini menggunakan metoda deskriptif kualitatif dengan pendekatan fenomenologi. Penelitian ini mengarah pada pendeskripsian secara mendalam dari fenomena kecurangan pada beberapa kasus dana desa. Pemerintah merancang aplikasi Siskeudes dimaksudkan sebagai salah satu bentuk pengawasan terhadap pengelolaan keuangan desa agar dapat meminimalisir terjadinya kecurangan terhadap pengelolaan dana desa, sehingga perlu dilakukan analisis implementasi dengan tahapan pengelolaan dana desa menurut aturan pemerintah.

Penelitian ini mendeskripsikan antara implementasi pengelolaan dana desa di desa banyuanyar Boyolali dengan menggunakan aplikasi Siskeudes telah berbasis teknologi informasi dengan tahapan pengelolaan keuangan desa berdasarkan ketentuan Permendagri Nomor 113 Tahun 2014 (Peraturan Pemerintah Indonesia, 2014). Data yang digunakan penelitian ini adalah data primer yang didapatkan dari proses wawancara langsung dengan narasumber yang disertai bukti-bukti pendukung melalui dokumentasi. Narasumber dalam penelitian ini adalah sekretaris desa Banyuanyar Boyolali yang sekaligus merangkap tugas sebagai operator aplikasi Siskeudes.

\section{Teknik Analisis Data}

Teknik analisis data yang digunakan meliputi reduksi data, triangulasi, penyajian data dan penarikan kesimpulan. Teknik pertama dalam penelitian ini adalah reduksi data, menurut Milles dan Huberman (1992) reduksi data merupakan proses memilih data-data yang berkaitan dengan penelitian, dengan membuang data yang tidak penting atau tidak berkaitan dengan fokus penelitian mengenai tahapan pengelolaan dana desa dan aplikasi Siskeudes. Dengan demikian, apabila dalam hasil penelitian ditemukan data yang dianggap tidak diperlukan, tidak dikenal, dan tidak berkaitan dengan tahapan pengelolaan dana desa dan aplikasi Siskeudes maka akan dilakukan reduksi data.

Tahapan selanjutnya adalah memeriksa keabsahan data dan informasi yang telah diperoleh dengan menggunakan teknik triangulasi. Menurut Moleong (2004) triangulasi merupakan teknik yang dilakukan dengan cara membandingkan, memeriksa dan menilai informasi atau data yang diperoleh dengan melakukan metoda wawancara dengan beberapa narasumber dari sudut pandang yang berbeda serta mengumpulkan bukti melalui dokumentasi 
yang berupa kumpulan foto, untuk mendapatkan kebenaran informasi yang valid serta memperoleh gambaran mengenai informasi aplikasi Siskeudes.

Setelah informasi dan data yang diperoleh dinyatakan valid, maka tahap berikutnya yaitu penyajian data. Menurut Milles dan Huberman (1992) penyajian data merupakan sekumpulan informasi dari data yang telah disusun dan disajikan sesuai dengan fokus penelitian, sehingga selanjutnya dapat mempermudah pada proses penarikan kesimpulan. Penyajian data dapat dibentuk dalam uraian singkat, bagan, tabel, grafik, matriks dan flowchart. Penelitian ini penyajian data akan menyajikan data-data yang telah dipilih dan sesuai dengan fokus penelitian dalam bentuk tabel dan naratif sehingga mudah untuk dipahami.

Teknik terakhir yang digunakan dalam penelitian yaitu penarikan kesimpulan, dengan mengambil inti pokok pembahasan dari hasil penelitian dengan berdasarkan kumpulan-kumpulan bukti hasil penelitian melalui wawancara dan dokumentasi yang ditemukan dan telah dinyatakan valid.

\section{Hasil dan Pembahasan}

\section{Gambaran Objek Penelitian}

Desa Banyuanyar merupakan desa yang terletak di jalan utama antara SoloSemarang tepatnya di Kecamatan Ampel, Kabupaten Boyolali. Desa Banyuanyar memiliki jumlah penduduk sebanyak 2.495 jiwa dengan rincian 1.244 penduduk berjenis kelamin laki-laki dan 1.251 berjenis kelamin perempuan. Desa Banyuanyar terdiri dari sembilan Dukuh yang dibagi menjadi empat wilayah Kadus, pembagian untuk wilayah Kadus I terbagi atas empat dukuh, yaitu Dukuh Rekuning, Dukuh Grenjeng, Dukuh Banyuanyar, Dukuh Geneng. Wilayah Kadus II terdiri dari Dukuh Bunder dan Dukuh Ngemplak. Sedangkan wilayah Kadus III hanya Dukuh-Dukuh dan untuk wilayah Kadus IV terdiri dari Dukuh Wangan dan Dukuh Jumbleng. Rata-rata tingkat pendidikan dari sembilan Dukuh tersebut yaitu pada tingkat Sekolah Lanjutan Tingkat Atas (SLTA). 


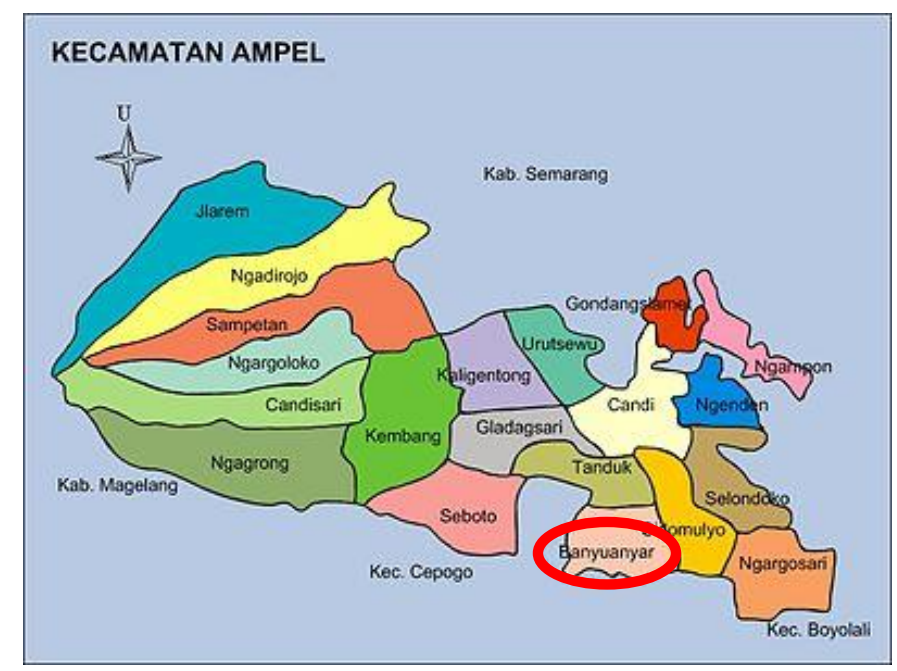

Sumber: Data Primer

\section{Gambar 2. Peta Desa Banyuanyar}

Visi dan Misi Desa Banyuanyar terbentuk atas dasar cita-cita dari Bapak Komarudin yang merupakan Kepala Desa Banyuanyar Boyolali. Visi yang ingin dicapai oleh Kepala Desa Banyuanyar adalah terwujudnya Banyuanyar sebagai desa berbasis pertanian, vokasi dan susu perah yang mandiri beriman dan bertaqwa. Agar visi tersebut dapat terwujud maka Kepala Desa melaksanakan dengan misi sebagai berikut:

1) Peningkatan sarana prasarana bidang infrasruktur perdesaan. Dengan membuat jalan dan jembatan baru serta melakukan pelebaran jalan empat meter sampai dengan delapan meter. Selain itu juga meningkatkan sarana penerangan di sepanjang jalan utama desa. Hal ini dilakukan untuk memberikan kelancaran dan kenyamanan bagi masyarakat dalam melakukan transportasi, sehingga dapat mempercepat proses arus perekonomian masyarakat; 2) Peningkatan sarana air bersih berkecukupan. Pemerintah desa mendorong dengan membuat gerakan Biopori, membangun Embung desa dengan luas 5 ha, membuat sumur bor, dan juga mengalirkan air dari perusahaan air minum daerah agar kebutuhan air masyarakat selalu tercukup; 3) Peningkatan akses masyarakat miskin kepada informasi lokal hingga global. Pemerintah desa memfasilitasi 10 titik wifi sehingga masyarakat dapat menggunakan internet secara gratis untuk mengakses berbagai macam informasi yang dibutuhkan; 4) Peningkatan pendapatan masyarakat, meskipun tanah pertanian sempit namun pemerintah desa akan mengoptimalkan hasil pertanian dengan menggali dan menciptakan potensi masyarakat setempat. Peningkatan pendapatan tersebut dicapai melalui pembinaan kepada Kelompok Tani Ternak Sido Makmur dan telah melakukan kerjasama antar pengolah susu sapi perah dengan Dinas Peternakan dan BPTP Semarang. Selain 
hal tersebut, dengan melihat potensi yang ada pada bidang perkebunan, pemerintah desa mengembangkan program One Village One Product (OVOP). Tanaman yang dikembangkan yaitu tanaman kopi dan kelengkeng.

Bapak Komarudin, ST yang menjabat sebagai Kepala Desa menempati kedudukan tertinggi dalam struktur organisasi pemerintahan desa di Desa Banyuanyar Boyolali. Kepala desa memiliki tugas sebagai penyelenggara pemerintah desa, melaksanakan pembangunan sarana prasarana perdesaan, memberikan pembinaan dan pemberdayaan kemasyarakatan. Dalam melaksanakan dan menyiapkan pengelolaan administrasi pemerintahan desa, kepala desa dibantu oleh Bapak Sriyono, A.Md yang menjabat sebagai Sekretaris Desa. Tugas sekretaris desa adalah melaksanakan urusan ketatausahaan administrasi umum maupun keuangan, seperti administrasi sumber pendapatan dan pengeluaran, inventarisasi, pengadministrasian aset, menyusun laporan dan ikut serta dalam menyusun RAPBDes.

Dalam menjalankan tugas, Sekretaris Desa membawahi dua staf bagian yaitu Bapak Waluyo yang menjabat sebagai Kaur Keuangan dan Bapak Suhudi selaku Kaur Umum dan Perencanaan. Kaur keuangan membantu sekretaris desa dalam melaksanakan pengelolaan sumber pendapatan desa, pengelolaan administrasi keuangan desa dan mempersiapkan bahan penyusunan APBDes. Kaur umum dan perencanaan membantu dalam melaksanakan administrasi umum, tata usaha dan kearsipan, pengelolaan inventaris kekayaan desa, dan mempersiapkan bahan rapat dan laporan.

Bagian Pemerintahan Desa lainnya seperti Kasi Pemerintahan, Kasi Kesra dan Pelayanan, Kadus I, Kadus II, Kadus III, dan Kadus IV memiliki tugas dan tanggungjawabnya masing-masing dalam membantu melaksanakan tugas dari kepala desa. Kasi pemerintahan yang dijabat oleh Ibu Sri Gayatmi membantu kepala desa dalam melaksanakan pengelolaan administrasi kependudukan, administrasi pertanahan dan melaksanakan kegiatan kemasyarakatan dalam upaya menciptakan ketentraman dan ketertiban masyarakat. Kasi kesra dan pelayanan yang dijabat oleh Bapak Alif Komarudin, ST bertugas untuk membantu dalam menyusun rencana, pelaksanaan dan laporan pelaksanaan di bidang kesejahteraan rakyat. Masing-masing Kepala Dusun yang terbagi dalam empat wilayah, membantu mengawasi pelaksanaan pembangunan maupun melaksanakan pembinaan dan pemberdayaan di wilayahnya masing-masing. Struktur organisasi di Desa Banyuanyar disajikan dalam Gambar 3. 


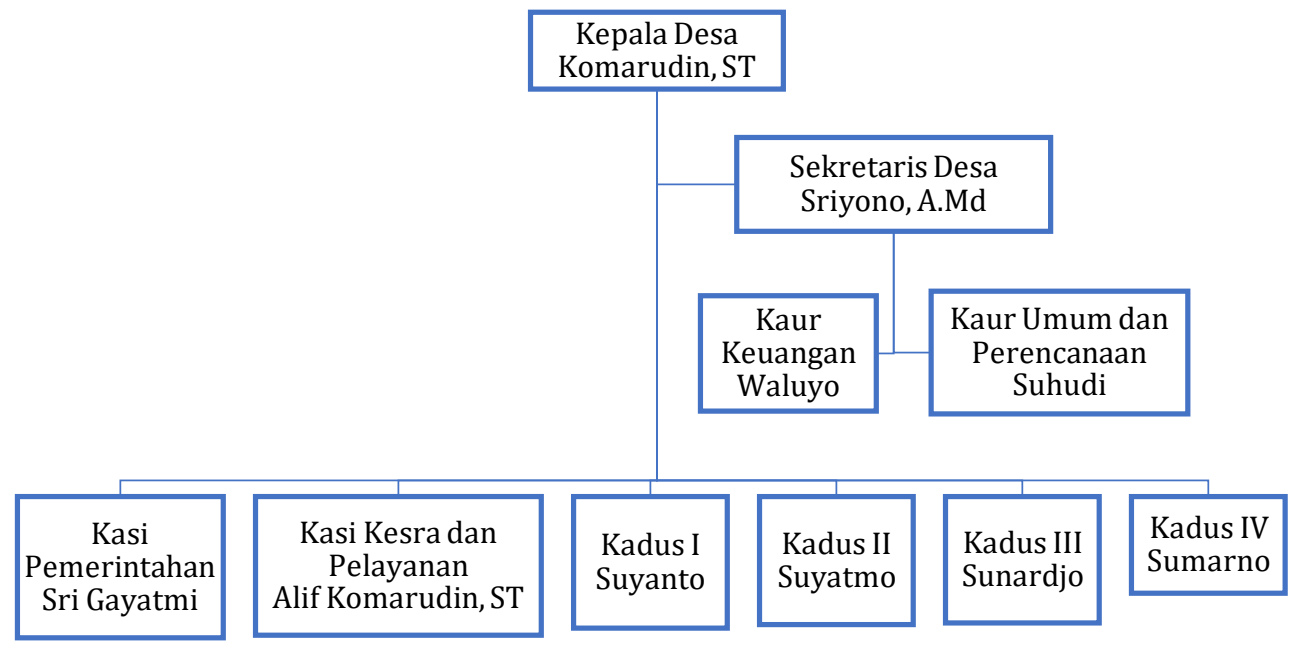

Sumber : Data Primer (Banyuanyar 2017)

Gambar 3. Struktur Organisasi Desa Banyuanyar Boyolali

\section{Tahapan Pengelolaan Dana Desa di Desa Banyuanyar Boyolali}

\section{Perencanaan}

Tahap pertama dalam pengelolaan dana desa di Desa Banyuanyar yaitu tahap perencanaan. Dalam tahapan ini dilakukan Musyawarah Rencana Pembangunan (Musrenbang) yang dihadiri oleh Pemerintah Desa serta perwakilan masyarakat setempat. Musrenbang dilaksanakan pada bulan Februari satu tahun sebelum tahun pelaksanaan pengelolaan dana desa. Landasan dari kegiatan Musrenbang yaitu membahas dan berpendapat mengenai Rencana Pembangunan Jangka Menengah Desa (RPJMDes) enam tahunan yang telah dibentuk oleh Kepala Desa Banyuanyar. RPJMDes harus diselesaikan paling lambat tiga bulan sejak masa pelantikan Kepala Desa. Output yang dihasilkan setelah penetapan RPJMDes yaitu Rancangan Kerja Pemerintah Desa (RKPDes). Setelah RKPDes yang baru telah diterbitkan maka selanjutnya akan dimasukkan kedalam APBDes. APBDes dibentuk pada bulan Oktober dan sesuai dengan Peraturan Desa APBDes maksimal sudah harus diputuskan pada tanggal 31 Desember untuk tahun yang bersangkutan. Hal ini sesuai dengan pernyataan dari Sekretaris Desa Banyuanyar yang menyatakan bahwa:

“Jadi n tahun minus 1 itu kita ada Musrenbang untuk tahun yang akan datang, dari Musrenbang hasilnya outputnya adalah RKPDes, Musrenbang acuannya dari RPJMDes 6 tahunan. Musrenbang dilaksanakan Februari n-1. Selanjutnya 
dari hasil musrenbang muncul skala prioritas yang dibangun pada tahun depan, setelah muncul di RKPDes baru dimasukan di APBDes. RKPDes itu September munculnya Perdes. Idealnya APBdes itu dibuatnya dibulan Oktober tapi maksimal Perdesnya itu tanggal 31 Desember n-1. APBdes 2019 itu sudah diputuskan 31 Desember 2018".

\section{Pelaksanaan}

Kegiatan pada tahapan pelaksanaan di Desa Banyuanyar dilakukan oleh Pemegang Kekuasaan Pengelolaan Keuangan Desa (PKPKD) yaitu kepala desa, Pelaksana Teknis Pengelolaan Keuangan Desa (PTPKD) yang dikoordinasi oleh Sekretaris Desa, Kaur Keuangan dan Tim Pelaksana Kegiatan (TPK). Ketika APBDes telah dianggarkan, maka kepala desa menunjuk TPK dari tokoh masyarakat untuk melaksanakan di lapangan. Setiap kegiatan pelaksanaan di lapangan yang telah selesai dilakukan, dilanjutkan dengan pelaksana teknis atau operator Siskeudes membuat Surat Permintaan Pembayaran (SPP) kepada Kepala Desa dalam rangka permintaan pencairan dana untuk kegiatan yang bersangkutan.

Kemudian SPP atas kegiatan tersebut diverifikasi oleh sekretaris desa untuk diperiksa kelengkapan dan kebenarannya. Setelah diverifikasi maka diajukan kepada kepala desa untuk meminta persetujuan berupa tanda tangan. Ketika dokumen SPP sudah lengkap ditanda tangani oleh kepala desa, sekretaris desa dan pelaksana teknis maka diserahkan kepada kaur keuangan untuk dilakukan proses pembayaran. Pembayaran dilakukan melalui rekening desa dengan menggunakan Bank Boyolali. Hal ini sesuai dengan pernyataan dari Sekretaris Desa Banyuanyar yang menyatakan bahwa:

"Pada tahapan pelaksanaan kegiatannya kita ada PKPKD, PTPKD, Bendahara, dan TPK. Ketika sudah dianggarkan maka kepala desa menunjuk TPK untuk melaksanakan di lapangan. TPK itu bisa dari Kadus bisa juga dari tokoh masyarakat, kalau disini TPKnya tokoh masyarakat semua. Ketika pelaksanaan di lapangan sudah dilakukan, kita pakai non cash transaction atau pencairannya menggunakan surat permintaan pembayaran kita pakai yang definitif. Permintaan pembayaran diverifikasi oleh Sekdes, lalu dimintakan persetujuan kepada kepala desa. Setelah dokumennya lengkap diturunkan kepada bendahara untuk dilakukan proses pembayaran dengan menggunakan rekening kas desa melalui Bank Boyolali."

\section{Penatausahaan}

Tahapan penatausahaan merupakan pencatatan transaksi pada setiap aktivitas yang terjadi seperti penerimaan kas, pengeluaran kas, pajak dan pendapatan bunga yang setiap bulannya harus dilakukan tutup buku dan telah diverifikasi oleh sekretaris desa dibantu dengan kaur keuangan sebelum dilaporkan 
kepada kepala desa. Output yang dihasilkan dari pencatatan transaksi tersebut salah satunya seperti Buku Kas Umum Desa, Buku Pembantu Bank, dan Buku Pembantu Pajak. Hal ini sesuai dengan pernyataan dari Sekretaris Desa Banyuanyar yang menyatakan bahwa:

"Penatausahaan itu segala sesuatu yang berhubungan dengan transaksi harian seperti pembayaran kas, penerimaan kas, pajak, bunga. Nah nanti lihat laporannya di laporan penatausahaan contohnya buku kas umum. Keuangan itu sebenarnya sentralnya ada di sekdes tapi dibantu kaur keuangan, sekdes sebagai verifikator, ya udah verifikasi terus sebelum disampaikan ke kepala desa."

\section{Pelaporan}

Pelaporan yang dilakukan oleh Pemerintah Desa Banyuanyar menggunakan dua cara, yaitu pelaporan secara online melalui aplikasi Siskeudes dan pelaporan hardcopy yang memerlukan lampiran bukti seperti kuitansi. Pelaporan melalui aplikasi Siskeudes secara otomatis dapat dikontrol dan diawasi oleh Kabupaten Boyolali dan Kementerian Keuangan. Sedangkan pelaporan hardcopy, dilaporkan kepada pihak yang memberikan bantuan dana. Hal ini sesuai dengan pernyataan dari Sekretaris Desa Banyuanyar yang menyatakan bahwa:

"Sekarang pelaporan ada dua, yang satu secara online , online itu di Kabupaten, pusat sudah mengetahui karena Siskeudes kita sudah online. Kedua kita hardcopy sebagai barang bukti seperti kuitansi yang tidak bisa diinputkan. Pelaporannya juga tergantung dari dananya, kalau dari BanProv itu ke Provinsi, kalo murni APBDes cukup ke Kabupaten. Kalo pelaporannya online kemungkinan sudah sampai pusat (Kementerian Keuangan)."

Dalam periode satu tahun, Desa Banyuanyar melakukan empat tahap pelaporan yang dilaporkan setiap tiga bulan sekali atau laporan triwulanan yang disampaikan oleh kaur keuangan kepada kepala desa. Laporan tersebut berupa hardcopy yang terdiri dari Laporan Realisasi Anggaran Desa, Laporan Realisasi Anggaran Desa Per Kegiatan dan Laporan Realisasi Anggaran Bulanan. Hal ini sesuai dengan pernyataan dari Sekretaris Desa Banyuanyar:

"Dalam 1 tahun melakukan 4 tahap pelaporan semester tiap triwulan, biasanya isinya rekap 3 bulan sama bulan 123 , yang bulanan tetep sendiri-sendiri tapi nanti ada rekapan yang 3 bulannya. Laporan triwulanan disampaikan oleh bendahara kepada kepala desa. Pertama yang dilaporkan itu yang bulanan realisasi anggaran, realisasi anggaran desa terus realisasi anggaran per kegiatan. Ini laporannya dari bendahara ke kepala desa." 


\section{Pertanggungjawaban}

Bapak Komarudin, ST selaku Kepala Desa bertanggungjawab kepada Kabupaten Boyolali atas laporan realisasi APBDes yang terdiri dari laporan semester pertama dan kedua pada setiap akhir tahun yang dianggarkan 31 Desember sesuai dengan Peraturan Desa. Salah satu lampiran yang terdapat pada dalam laporan pertanggungjawaban tersebut yaitu Laporan Realisasi Anggaran Desa, Laporan Realisasi APBDes per Sumberdana 1a dan 1b. Hal ini sesuai dengan pernyataan dari Sekretaris Desa Banyuanyar:

"Kalau kepala desa ke Kabupaten yang dilaporkan itu laporan realisasi semesteran ada 2, semester pertama sama semester kedua dalam bentuk hardcopy. Biasanya dilaporkan pada akhir tahun anggaran 31 Desember sesuai dengan PerDes. Itu lampirannya kalau dari siskeudes laporan realisasi anggaran desa, laporan sumberdana $1 \mathrm{a}$ dan $1 \mathrm{~b} . "$

Berdasarkan hasil dan pembahasan pengelolaan dana desa di Banyuanyar Boyolali maka dapat disajikan dalam bagan yang disajikan pada Gambar 4.

Tahapan Pengelolaan Dana Desa di Desa Banyuanyar Boyolali

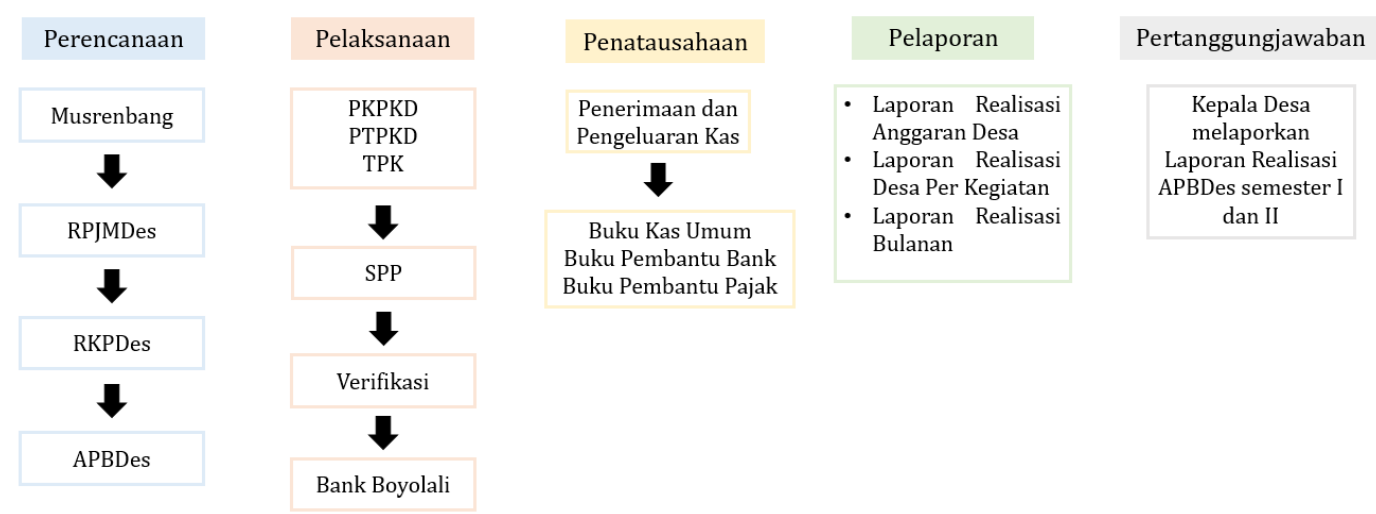

\section{Gambar 4. Bagan Tahapan Pengelolaan Dana Desa di Desa Banyuanyar Boyolali}

\section{Tahapan Pengelolaan Dana Desa menurut Aplikasi Siskeudes (Versi V1.2.RI.0.6) di Desa Banyuanyar Boyolali}

\section{Perencanaan}

Kegiatan Musrenbang yang diadakan oleh Pemerintah Desa Banyuanyar yang dihadiri oleh perwakilan masing-masing lembaga dan tokoh masyarakat setempat menghasilkan output RKPDes. Tahap pertama yang harus diinput oleh sekretaris desa adalah pada menu data entri modul perencanaan pada form perencanaan visi misi dan RPJM desa (Lampiran I). 
Sebelum menginput data APBDes baru, maka harus dipastikan telah menginput RPJMDes dan RKPDes pada bulan September. Setelah dipastikan sudah diinput, tahap berikutnya menginput APBDes baru di bulan Oktober, pada menu data entri modul penganggaran, menginput data anggaran yang terdiri dari data umum desa, kegiatan, pendapatan, belanja, pembayaran 1 dan pembayaran 2 . Data-data yang telah diinput menghasilkan laporan APBDes yang akan dikirimkan kepada Kabupaten Boyolali dalam bentuk hardcopy untuk dievaluasi atas ketentuan jumlah anggaran dan pendapatan yang akan digunakan tersebut untuk kegiatan apa saja. Kemudian, apabila laporan APBDes lolos evaluasi dari Bupati melalui camat, maka APBDes baru dapat diposting melalui Siskeudes, karena syarat untuk posting APBDes adalah lolos evaluasi. Bentuk Laporan APBDes Desa Banyuanyar yang telah diposting oleh Sekretaris Desa Banyuanyar (Lampiran I).

\section{Pelaksanaan}

Setelah TPK selesai melakukan pekerjaannya, maka sekretaris desa melakukan input data pada form SPP pelaksana kegiatan dari menu data entri modul penatausahaan SPP kegiatan SPP definitif. Tujuan input data pada SPP definitif adalah untuk membuat surat permohonan pencairan untuk kegiatan yang telah selesai dikerjakan agar dapat segera dibayarkan oleh kaur keuangan melalui rekening kas desa dari Bank Boyolali (Lampiran I).

Hasil output dari form SPP definitif juga menjadi salah satu lampiran dalam laporan pertanggungjawaban dana desa sebagai bukti. Sesuai prosedur lampiran tersebut harus ditanda tangani dan distempel oleh Bapak Komarudin, ST selaku Kepala Desa dan Bapak Waluyo selaku Kaur Keuangan Desa Banyuanyar. Lampiran tersebut terdiri dari kuitansi pengeluaran, SPP-1, SPP2, dan Surat Pernyataan Tanggung Jawab Belanja (SPTB) (Lampiran I).

\section{Penatausahaan}

Sebelum melakukan tahap penatausahaan, dipastikan bahwa nomor rekening bank desa telah diinput dengan benar, APBDes telah diposting dan menginput saldo awal. Tahap penatausahaan merupakan kegiatan pencatatan transaksi atas setiap kegiatan yang terjadi, seperti penerimaan dan pengeluaran kas. Mencatat transaksi penerimaan pada menu data entri modul penatausahaan untuk menginput seluruh penerimaan di Desa Banyuanyar dengan mengisi secara rinci mulai dari kolom tanggal, jumlah dan penanggungjawab penerimaan tunai, bank penyetoran dan swadaya non kas (Lampiran I).

Hasil output atas pencatatan penerimaan kegiatan tersedia pada menu laporan modul penatausahaan, yang salah satunya berupa buku kas umum desa. Buku kas umum desa menjadi sarana pengendalian bagi kaur keuangan Desa 
Banyuanyar terhadap jumlah kas yang dipegang dengan jumlah batas maksimal uang kas yang harus dibawa sebesar Rp 5.000.000,00. Sekretaris desa secara berkala memverifikasi atas jumlah kas yang dibawa oleh kaur keuangan dengan saldo yang ada di buku kas umum desa (Lampiran I).

Selain itu output yang dihasilkan dari pencatatan penerimaan kegiatan yaitu buku pembantu bank. Buku tersebut dapat digunakan sebagai alat pengendalian antara buku pembantu bank di Siskeudes dengan buku bank dari Bank Boyolali. Apabila jumlah saldo akhir antara buku pembantu bank dengan buku bank Boyolali tidak sama maka telah terjadi kesalahan. Kaur Keuangan bertanggungjawab atas buku bank Boyolali dengan verifikasi dari Sekretaris Desa yang melakukan kontrol buku pembantu bank melalui Siskeudes (Lampiran I).

Output lainnya adalah buku kas pembantu pajak yang digunakan sebagai pengendalian atas potongan dan setoran pajak yang dilakukan oleh Kaur Keuangan, sehingga dapat dipantau mengenai kewajiban pajak apa saja yang telah dilakukan oleh kaur keuangan melalui aplikasi Siskeudes. Sekretaris Desa secara berkala memverifikasi seluruh aktivitas kegiatan pencatatan penerimaan dan pengeluaran seperti buku kas umum, buku pembantu bank dan buku pembantu pajak melalui Siskeudes (Lampiran I).

\section{Pelaporan}

Pelaporan secara online melalui aplikasi Siskeudes yang dimaksud adalah ketika telah selesai menginput seluruh form pada menu data entri modul penganggaran dan penatausahaan. Hasil output laporannya tersedia pada menu laporan modul pembukuan yaitu form Laporan Keuangan Desa (Lampiran I).

Aplikasi Siskeudes Desa Banyuanyar telah terhubung dengan server yang khusus dimiliki oleh Kabupaten Boyolali, maka dalam sistem pelaporan online dari Kabupaten Boyolali dapat memeriksa langsung data-data yang telah diinputkan dalam Siskeudes dari berbagai Desa yang ada di Kabupaten Boyolali dan salah satunya termasuk Desa Banyuanyar. Selain itu aplikasi Siskeudes online juga dilengkapi pengawasan secara real time dengan adanya keterangan tanggal, tempat dan waktu (Lampiran I).

\section{Pertanggungjawaban}

Laporan pertanggungjawaban yang dilaporkan oleh kepala desa adalah laporan realisasi APBDes semester pertama dan semester kedua kepada Kabupaten Boyolali. Selain itu juga melampirkan Laporan Realisasi Anggaran Desa, Laporan Realisasi APBDes per Sumber dana 1a dan Laporan Realisasi APBDes per Sumber dana 1b pada menu laporan modul pembukuan aplikasi Siskeudes. 
Pada tahapan pertanggungjawaban melalui aplikasi Siskeudes, mengambil hasil output pada menu laporan modul pembukuan pada form laporan keuangan desa untuk melengkapi bukti lampiran laporan pertanggungjawaban salah satunya Laporan Realisasi Pelaksanaan APBDes Desa Banyuanyar (Lampiran I).

Berdasarkan hasil dan pembahasan yang telah disajikan diatas, sesuai dengan tujuan penelitian maka akan menganalisis implementasi tahapan pengelolaan keuangan desa berdasarkan Permendagri 113 Tahun 2014 dengan tahapan pengelolaan dana desa di desa Banyuanyar melalui aplikasi Siskeudes (Versi V1.2.RI.0.6) yang disajikan dalam Tabel 1. Berdasarkan tabel analisis menunjukkan bahwa antara pengelolaan keuangan desa Permendagri 113 tahun 2014 dengan pengelolaan dana desa melalui aplikasi Siskeudes (Versi V1.2.RI.0.6) Desa Banyuanyar Boyolali mulai dari tahapan perencanaan, pelaksanaan, penatausahaan, pelaporan dan pertanggungjawaban telah terimplementasi dengan baik. Meskipun terdapat sedikit perbedaan pada pengimplementasian tahapan pertanggungjawaban yang tidak melakukan proses penginputan pada laporan pertanggungjawaban melalui aplikasi Siskeudes, namun peran Siskeudes hanya melengkapi lampiran-lampiran yang dibutuhkan sebagai bukti dalam pelaporan pertanggungjawaban. Namun hal tersebut tidak mempengaruhi proses pengelolaan dana desa Banyuanyar. 
Tabel 1. Analisis Implementasi Pengelolaan Dana Desa dengan Aplikasi Siskeudes (Versi V1.2.RI.0.6) Desa Banyuanyar

\begin{tabular}{|c|c|c|c|}
\hline $\begin{array}{l}\text { Pengelolaan Keuangan } \\
\text { Desa Permendagri } 113 \\
\text { Tahun } 2014\end{array}$ & $\begin{array}{c}\text { Pengelolaan Dana Desa Desa } \\
\text { Banyuanyar }\end{array}$ & $\begin{array}{c}\text { Pengelolaan Dana Desa } \\
\text { Aplikasi Siskeudes (Versi } \\
\text { V1.2.RI.0.6) Desa Banyuanyar }\end{array}$ & Keterangan \\
\hline $\begin{array}{l}\text { 1. Perencanaan } \\
\text { Kegiatan: } \\
\text { a. Menyusun Rancangan } \\
\text { Peraturan Desa mengenai } \\
\text { APBDes atas dasar RKPDes } \\
\text { tahun yang bersangkutan } \\
\text { oleh sekretaris desa dan } \\
\text { disampaikan kepada } \\
\text { kepala desa. }\end{array}$ & $\begin{array}{l}\text { 1. Perencanaan } \\
\text { Kegiatan: } \\
\text { a. Melakukan Musrenbang yang } \\
\text { menghasilkan RKPDes, dan } \\
\text { dimasukan ke dalam APBDes } \\
\text { untuk tahun yang } \\
\text { dianggarkan. }\end{array}$ & $\begin{array}{l}\text { 1. Perencanaan } \\
\text { Kegiatan : } \\
\text { a. Menginput Visi dan Misi Desa } \\
\text { Banyuanyar. } \\
\text { b. Menginput RPJMDes dan } \\
\text { RKPDes } \\
\text { c. Menginput APBDes baru. }\end{array}$ & $\begin{array}{l}\text { Tahapan perencanaan sama-sama bertujuan } \\
\text { untuk menyusun APBDes dengan dasar } \\
\text { RKPDes. Bedanya Desa Banyuanyar } \\
\text { melakukan Musrenbang dengan melibatkan } \\
\text { partisipasi dari masyarakat setempat dalam } \\
\text { menyusun RKPDes. } \\
\text { Tahap perencanaan menurut Permendagri } \\
\text { tidak terdapat visi misi, sedangkan melalui } \\
\text { Siskeudes menginput secara bertahap mulai } \\
\text { dari visi misi, RPJMDes, RKPDes, dan APBDes. }\end{array}$ \\
\hline $\begin{array}{l}\text { 2. Pelaksanaan Kegiatan: } \\
\text { a. Pengeluaran dan } \\
\text { penerimaan } \\
\text { menggunakan rekening } \\
\text { desa dilengkapi bukti yang } \\
\text { sah. } \\
\text { b. TPK mengajukan SPP } \\
\text { dengan melampirkan } \\
\text { bukti transaksi yang telah } \\
\text { diperiksa oleh sekretaris } \\
\text { desa dengan persetujuan } \\
\text { kepala desa. }\end{array}$ & $\begin{array}{l}\text { 2. Pelaksanaan Kegiatan: } \\
\text { a. Pembayaran dilakukan } \\
\text { melalui rekening desa dengan } \\
\text { menggunakan Bank Boyolali } \\
\text { dengan melampirkan bukti } \\
\text { yang sah. } \\
\text { b. Pelaksana teknis atau } \\
\text { operator Siskeudes membuat } \\
\text { SPP yang telah diverifikasi } \\
\text { sekretaris desa dan diajukan } \\
\text { kepada kepala desa untuk } \\
\text { meminta tanda tangan } \\
\text { persetujuan. }\end{array}$ & $\begin{array}{l}\text { 2. Pelaksanaan Kegiatan: } \\
\text { a. Menginput pada form SPP } \\
\text { pelaksana kegiatan dari data } \\
\text { entri penatausahaan SPP } \\
\text { kegiatan, yang terdiri dari } \\
\text { panjar kegiatan, SPP definitif, } \\
\text { dan SPP pembiayaan. Output } \\
\text { dari form tersebut adalah } \\
\text { berupa kuitansi pengeluaran, } \\
\text { SPP-1, SPP-2, dan SPTB. }\end{array}$ & $\begin{array}{l}\text { Tujuan dari tahapan pelaksanaan dari } \\
\text { ketiganya adalah seluruh pengeluaran dan } \\
\text { penerimaan dilakukan melalui rekening desa } \\
\text { dengan melampirkan bukti yang sah. Bukti } \\
\text { tersebut salah satunya dapat dibuat melalui } \\
\text { aplikasi Siskeudes, dengan menginput pada } \\
\text { form SPP definitif dan output dijadikan sebagai } \\
\text { bukti. }\end{array}$ \\
\hline
\end{tabular}




\begin{tabular}{|c|c|c|c|}
\hline $\begin{array}{l}\text { 3. Penatausahaan Kegiatan: } \\
\text { a. Penerimaan dan } \\
\text { pengeluaran kas dan } \\
\text { melakukan tutup buku } \\
\text { setiap akhir bulan secara } \\
\text { tertib. }\end{array}$ & $\begin{array}{l}\text { 3. Penatausahaan Kegiatan: } \\
\text { a. Pencatatan transaksi setiap } \\
\text { aktivitas yang terjadi seperti } \\
\text { penerimaan kas, pengeluaran } \\
\text { kas, pajak dan pendapatan } \\
\text { bunga yang setiap akhir bulan } \\
\text { dilakukan tutup buku. }\end{array}$ & $\begin{array}{l}\text { 3. Penatausahaan Kegiatan : } \\
\text { a. Input pada menu data entri } \\
\text { modul penatausahaan pada } \\
\text { form Penerimaan Desa. } \\
\text { b. Output penatausahaan terdiri } \\
\text { dari Buku Kas Umum Desa, } \\
\text { Buku Pembantu Bank, Buku } \\
\text { Kas Pembantu Pajak. }\end{array}$ & $\begin{array}{l}\text { Tahapan penatausahaan dari ketiganya sama- } \\
\text { sama bertujuan untuk pembuatan pencatatan } \\
\text { atas setiap kegiatan transaksi, yang dapat } \\
\text { diinput melalui Siskeudes salah satunya dapat } \\
\text { menghasilkan output Buku Kas Umum Desa, } \\
\text { Buku Pembantu Bank, dan Buku Kas Pembantu } \\
\text { yang selalu diverifikasi oleh sekretaris desa. }\end{array}$ \\
\hline $\begin{array}{l}\text { 4. Pelaporan Kegiatan: } \\
\text { a. Kepala desa } \\
\text { menyampaikan laporan } \\
\text { realisasi pelaksanaan } \\
\text { APBDes semester pertama } \\
\text { dan semester akhir } \\
\text { kepada bupati/walikota. }\end{array}$ & $\begin{array}{l}\text { 4. Pelaporan Kegiatan : } \\
\text { a. Kepala desa melaporkan } \\
\text { laporan realisasi APBDes } \\
\text { semester pertama dan kedua } \\
\text { ke Kabupaten Boyolali } \\
\text { b. Dua cara pelaporan yaitu } \\
\text { pelaporan secara online } \\
\text { melalui aplikasi Siskeudes dan } \\
\text { pelaporan hardcopy yang } \\
\text { memerlukan lampiran bukti. }\end{array}$ & $\begin{array}{l}\text { 4. Pelaporan Kegiatan: } \\
\text { a. Melakukan input pada menu } \\
\text { data entri modul perencanaan } \\
\text { dan penatausahaan. Hasil } \\
\text { output laporannya tersedia } \\
\text { pada menu laporan modul } \\
\text { pembukuan dengan form } \\
\text { laporan keuangan desa. }\end{array}$ & $\begin{array}{l}\text { Tahapan pelaporan memiliki tujuan yang sama } \\
\text { yaitu melaporkan laporan realisasi } \\
\text { pelaksanaan APBdes semester pertama dan } \\
\text { kedua kepada Kabupaten Boyolali yang } \\
\text { disampaikan oleh kepala desa. Proses } \\
\text { pelaporan ada } 2 \text { cara yaitu online melalui } \\
\text { Siskeudes dengan menginput pada modul } \\
\text { perencanaan dan penatausahaan dengan } \\
\text { output pada menu laporan modul pembukuan } \\
\text { dan pelaporan hardcopy dengan lampiran } \\
\text { bukti. }\end{array}$ \\
\hline $\begin{array}{l}\text { 5. Pertanggungjawaban } \\
\text { Kegiatan : } \\
\text { a. Laporan } \\
\text { pertanggungjawaban } \\
\text { realisasi pelaksanaan } \\
\text { APBDes disampaikan oleh } \\
\text { kepala desa kepada } \\
\text { bupati/walikota setiap } \\
\text { akhir tahun anggaran. }\end{array}$ & $\begin{array}{l}\text { 5. Pertanggungjawaban } \\
\text { Kegiatan: } \\
\text { a. Laporan pertanggungjawaban } \\
\text { dilakukan setiap akhir tahun } \\
\text { anggaran oleh kepala desa } \\
\text { sesuai dengan PerDes pada } \\
\text { tanggal } 31 \text { Desember. }\end{array}$ & 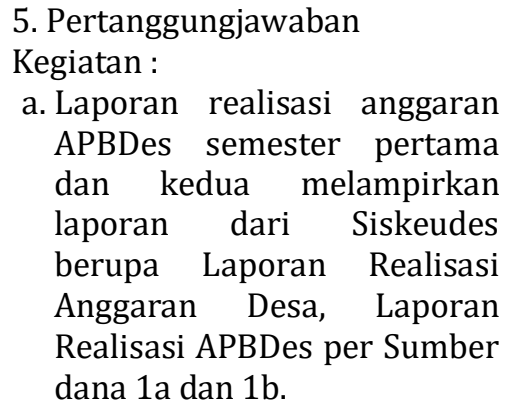 & $\begin{array}{l}\text { Tahapan pertanggungjawaban } \begin{array}{r}\text { bertujuan } \\
\text { untuk maporan }\end{array} \\
\text { pertanggungjawaban realisasi pelaksanaan } \\
\text { APBDes kepada bupati/walikota oleh Kepala } \\
\text { Desa. Perbedaannya pada aplikasi Siskeudes } \\
\text { yang hanya menjadi pelengkap dalam lampiran } \\
\text { bukti pada laporan pertanggungjawaban }\end{array}$ \\
\hline
\end{tabular}


Hasil analisis ini, menunjukkan bahwa peran aplikasi Siskeudes dapat dijadikan sebagai sarana pengawasan pengelolaan keuangan desa, dilihat dari seluruh tahapan pengelolaan dana desa Banyuanyar yang telah terimplementasikan berdasarkan Permendagri 113 tahun 2014 juga penginputan melalui aplikasi Siskeudes online secara real time yang tercantum keterangan tanggal, tempat dan waktu yang langsung terhubung dengan server Kabupaten Boyolali, sehingga Kabupaten Boyolali dan Kementerian Keuangan dapat langsung mengawasi dan mengontrol pengelolaan keuangan desa Banyuanyar. Secara umum tidak terdapat masalah dalam pengimplementasian pengelolaan dana desa menggunakan aplikasi Siskeudes dikarenakan desa tersebut merupakan desa yang berbasis online dan menjadikan desa Banyuanyar Boyolali menjadi desa percontohan.

\section{Simpulan}

Berdasarkan hasil analisis tahapan pengelolaan keuangan desa Permendagri 113 tahun 2014 dengan tahapan pengelolaan dana desa Banyuanyar melalui aplikasi Siskeudes (Versi V1.2.RI.0.6), maka dapat disimpulkan bahwa seluruh tahapan mulai dari perencanaan, pelaksanaan, penatausahaan, pelaporan sampai dengan pertanggungjawaban telah terimplementasi dengan baik. Meskipun terdapat sedikit perbedaan pada tahapan pertanggungjawaban yang tidak melakukan proses penginputan pada laporan pertanggungjawaban melalui aplikasi Siskeudes, namun peran Siskeudes hanya melengkapi lampiran-lampiran yang dibutuhkan sebagai bukti dalam pelaporan pertanggungjawaban. Lebih lanjut, lampiran-lampiran tersebut tidak mempengaruhi proses pengelolaan dana desa Banyuanyar. Berdasarkan seluruh proses input pengelolaan dana desa melalui aplikasi Siskeudes online secara real time menunjukkan waktu, tempat dan tanggal dan langsung terhubung dengan server di Kabupaten Boyolali, menunjukkan bahwa aplikasi Siskeudes dapat berperan sebagai sarana pengawasan pengelolaan dana desa.

Secara umum implementasi pengelolaan dana desa menggunakan aplikasi Siskeudes tidak memiliki masalah yang berarti dalam pengoperasiannya dikarenakan memang desa Banyuanyar merupakan desa yang sudah terbuka dengan teknologi informasi dan memiliki SDM yang memiliki pengetahuan dan kemampuan yang baik dalam menggunakan aplikasi Siskeudes, sehingga tidak mengalami kendala yang berarti. Selain mengimplementasi pengelolaan dana desa menggunakan aplikasi Siskeudes, desa Banyuanyar memang menerima dana desa dengan keyakinan bahwa dana desa ini akan membangun desanya. Sehingga dalam pengelolaannya mereka benar-benar ingin sesuai dengan aturan yang berlaku dari pemerintah sehingga penempatan SDM di desa Banyuanyar sudah tepat. 
Keterbatasan dalam penelitian ini hanya memiliki satu narasumber yang memahami pengelolaan dana desa sekaligus merangkap sebagai operator aplikasi Siskeudes, sehingga informasi yang didapatkan kurang objektif. Saran bagi Pemerintah Desa Banyuanyar untuk tetap mempertahankan konsistensinya agar dapat mengelola dana desa dan mengimpementasikan aplikasi Siskeudes dengan baik. Bagi Pemerintah Desa yang sekaligus merangkap sebagai operator aplikasi Siskeudes, perlu dibantu dengan menambah SDM yang memiliki pengetahuan dan kemampuan dalam bidang teknologi informasi, sehingga dalam menjalankan tugasnya dapat lebih mempermudah dan mempercepat pengelolaan dana desa. Bagi penelitian selanjutnya, penelitian ini diharapkan dapat dijadikan pembanding untuk desa yang belum terbuka dengan teknologi informasi dan desa yang telah menerapkan kebijakan pengelolaan keuangan desa dengan Permendagri 20 Tahun 2018. Selain itu, penelitian selanjutnya juga diharapkan dapat mengidentifikasi masalah dalam implementasi aplikasi Siskeudes.

\section{Daftar Pustaka}

Afrizal, Mazaliza, Z., \& Khudri, A. (2016). Analisis Prosedur Pengelolaan Keuangan Desa Sungai Pinang Melalui Aplikasi Siskeudes, (12), 1-8.

Banyuanyar. (2017a). Anggaran Desa. https://banyuanyar.desa.id/profildesa-50Anggaran.Desa.html.

Banyuanyar. (2017b). Perangkat Desa. https://banyuanyar.desa.id/profildesa-47Perangkat.Desa.html.

Banyuanyar. (2017c). Sosok Di balik Green Smart Village. https://banyuanyar.desa.id/berita-3-Sosok.Di.balik.Green.Smart.Village.html.

Basori, A., Megantoro, R. G., \& Lasantu, A. I. (2016). Buku Kerja Aplikasi Sistem Keuangan Desa (SISKEUDES), 3-112.

Boyolali. (2018). Berita Smart City Terwujud Karena Komitmen Para Kepala Daerah. http://www.boyolali.go.id/detail/4112/smart-city-terwujud-karenakomitmen.

BPKP.

(2015).

Peluncuran

SISKEUDES. http://www.bpkp.go.id/sakd/konten/2454/Peluncuran-SISKEUDES.bpkp.

Darwin. (2017). Aplikasi Sistem Informasi Manajemen Daerah (Simda) Dalam Menciptakan Akuntabilitas Pengelolaan Alokasi Dana Desa ( Add ) Di Kabupaten Sinjai Regional.

Dewanti, E. D. W., Sudarno, \& Kurrohman, T. (2016). Analisis Perencanaan Pengelolaan Keuangan Desa Di Desa Boreng ( Studi Kasus Pada Desa Boreng Kecamatan Lumajang Kabupaten Lumajang ) Financial Management Planning Analysis For Villages Fund In Boreng Village ( Case Study at Boreng Lumajang Regency ). http://repository.unej.ac.id/bitstream/handle/123456789/73233/ELSA Dwi Wahyu Dewanti.pdf?sequence $=1$.

Juardi, M. S. S., Muchlis, M., \& Putri, R. A. (2018). Evaluasi Penggunaan Aplikasi Siskeudes Dalam Upaya Peningkatan Kualitas Akuntabilitas Keuangan Desa 
(Studi Pada Desa Jenetallasa Kec. Pallangga Kab. Gowa). Akuntansi Peradaban, 3017, 84-107.

Kementerian Komunikasi dan Informatika Republik Indonesia. (2017). BPKP Konsisten Mengawal Keuangan Desa. https://kominfo.go.id/content/detail/9658/bpkpkonsisten-mengawal-keuangan-desa/0/artikel_gpr.

Kementrian Keuangan Republik Indonesia. 2017. "Buku Saku Dana Desa." https://www.kemenkeu.go.id/media/6750/buku-saku-dana-desa.pdf.

Komisi Pemberantasan Korupsi nomor. 2016. "Surat Edaran Komisi Pemberantasan Korupsi NomorB7508/01-16/08/2016." http://www.bpkp.go.id/public/upload/unit/sakd/files/Surat Ketua KPK_kpd Kades.pdf.

Lapananda, Y. (2016). Hukum Pengelolaan Keuangan Desa (Buku 1). Jakarta: Penerbit Rmbooks.

Mamuaya, J. V., Sabijono, H., \& Gamaliel, H. (2017). Analisis Pengelolaan Keuangan Desa Berdasarkan Permendagri No. 113 Tahun 2014 (Studi Kasus di Desa Adow Kecamatan Pinolosian Tengah Kabupaten Bolaang Mongondow Selatan). Jurnal Riset Ekonomi, Manajemen, Bisnis Dan Akuntansi, 5(2), 1020-1030.

Mariana, D., \& Handayani, S. (2014). Pengelolaan \& Pertanggungjawaban Keuangan Desa. Yogyakarta: FPPD.

Milles, \& Huberman. (1992). Analisis Data Kualitatif. Jakarta: Universitas Indonesia Press.

Moleong, L. J. (2004). Metodologi Penelitian Kualitatif. Bandung: Remaja Rosdakarya.

Murtiono, Y., \& Wulandari. (2014). Perencanaan dan Penganggaran Desa. Yogyakarta: FPPD.

Peraturan Pemerintah Indonesia. (2014a). Peraturan Menteri Dalam Negeri Republik Indonesia Nomor 113 Tentang Pengelolaan Keuangan Desa.

Peraturan Pemerintah Indonesia. (2014b). Undang-Undang Republik Indonesia Nomor 6 Tahun 2014 Tentang Desa.

Pulungan, M. S. (2013). Optimalisasi Simda Dalam Mewujudkan Pengelolaan Keuangan Daerah Kab. Kutai Kartanegara Yang Lebih Berkualitas. Jurnal Bina Praja, 5, 301-316.

Putra, H. D. (2018). ICW Sebut Angka Korupsi Dana Desa Naik di 2018, Sudah 102 Kades Tersangka.

Rusmayanti, A., Purnama, B. E., \& Sukadi. (2010). Sistem Informasi Pengelolaan Keuangan. Indonesian Journal on Computer Science - Speed, 1979-9330, 1-5.

Rustiarini, Ni Wayan. 2016. "Good Governance Dalam Pengelolaan Dana Desa." Simposium Nasional Akuntansi, 1-18.

Surat Edaran Direktur Jenderal Bina Pemerintahan Desa Kementerian Dalam Negeri. 2016. "Surat Edaran Direktur Jenderal Bina Pemerintahan Desa Kementerian Dalam Negeri Nomor 145/8350/BPD." http://www.bpkp.go.id/public/upload/unit/sakd/files/Surat Edaran Dagri SISKEUDES.pdf. 